\title{
Sustainable Development (SDGs) of the Coastal Zone and Small Islands in Bima Regency
}

\author{
Nur Khaerah $^{1}$, Zaldi Rusnaedy ${ }^{2}$, Haeril $^{3}$, Ahmad Harakan $^{1}$ \\ \{nurkhaerah@unismuh.ac.id\} \\ Universitas Muhammadiyah Makassar, Indonesia ${ }^{1}$ \\ Universitas Panca Sakti Makassar, Indonesia ${ }^{2}$ \\ STISIP Bima, Indonesia ${ }^{3}$
}

\begin{abstract}
The Existence of the tendency of scarce land resources, the basic target of Indonesia's economic development will rely on coastal zones and small islands along with its sources. If they are not followed by the application of appropriate management policies, it can reduce the ability of coastal ecosystems and small islands in the provision of sustainable natural resources. This study aims to analyze the sustainable development of natural resources of coastal areas and small islands in the Bima Regency. By using qualitative research methods, this study shows that aspects of socio-economic development is still a problem with the number of communities pre-prosperous coastal areas that are still high and worsening environmental conditions marked by the narrowing of mangrove conservation areas.
\end{abstract}

Keywords: Sustainable Development (SDGs), coastal zones, small islands

\section{Introduction}

Indonesia is a country with a cluster of thousands of islands, so it is nicknamed as a maritime country with the most productive marine wealth. Beach zones and small islands and their sources become the foundation of economic development. Social and economic factors become an attraction for the development of coastal areas and small islands by the government. Coastal and small island resources in Indonesia are "economic giants that are still asleep". Potentials are such as physical potential, development, renewable resources, unrenewable resources and geopolitical potential, but not well managed [1]-[4].

Government policies in the development of coastal areas and small islands rely only on economic aspects without considering the environment and community empowerment. The topdown policy of the government makes people less participate in the preservation of natural resources, in fact, most of them behave destructively and threaten sustainable capacity. The topdown approach is an inappropriate choice in sustainable natural resource management and triggers vulnerability and damage by people who depend on natural resources [5]-[7].

Sustainable development is nothing but an effort to synchronize, synergize, and give equal weight to three aspects of development, namely economic, socio-cultural and environmental 
aspects. The idea behind it all is that economic, socio-cultural, and environmental development must be closely related to each other, so that the elements of this interrelated entity must not be separated or contradicted from one another.

The concept of sustainable development is the basis for ecological perspectives, which are developed primarily from the study of biological and physical systems which initially focused on population, species sustainability, pollution, energy and so on, which are then applied to economic and social systems [8], [9].

Bima Regency is a maritime area with a coastal and marine area of 3,572.31 km2 with people growing and developing in coastal areas. There are 155 small islands, 74 of which already have names and three of them have a population that is dense with potential natural resources for socioeconomic development of the community. The potential of these natural resources is threatened by destructive use by local communities with fishing activities using toxic and explosive materials. Seeing the threat, then it takes the government's efforts for the sustainable development of coastal areas and small islands [10].

\section{Method}

This article departs from the results of research using a qualitative research approach. The data used in this study were obtained from the Department of Marine and Fisheries, Environment Agency, Tourism Office, Community Supervisory Group (Pokmaswas), Non-Governmental Organizations (LSM) and the community of coastal environmental observers, as well as the Coastal District of Bima Regency. Data collection techniques used are observation, documentation and interviews. Data analysis techniques are data reduction, data presentation, and conclusions [11].

\section{Result And Discussion}

The development of coastal and small islands in Bima Regency is carried out as an effort of economic, social and environmental protection. Community of socio-economic development can be seen from the income redistribution and welfare. The number of damaged road infrastructure in coastal areas does not only cause difficult accessibility but also impacts on tourism development, coastal areas and small islands in Bima Regency become hampered. Even though the number of foreign tourists visiting KabupatenBima has greatly increased.

In 2016 there were 4,758 tourism visitors, which increased significantly compared to the previous year which was quiet from foreign tourists visiting. So as to respond that the provision of infrastructure, facilities and services as well as the accessibility of tourism is very important to do. Currently, lodging accommodation for domestic and foreign tourists in coastal sub-district tourism areas has increased. The provision of this facility as a step to support the economic income of coastal communities.

Bima Regency has 64 coastal villages with 14,201 people recorded as fishermen. However, the majority of fishermen looking for fish still use 1,203 forging boats, while those already using motorboats and motorized boats are 1,317 and 1,907 units respectively. In addition, there were 2,838 households that had aquaculture businesses in the coastal areas. The high number of 
underprivileged households in the coastal area is evidence of weakness in the social and economic development of the community in Bima Regency. The 2016 data shows the coastal area with 11166 poor families and 11707 prosperous families.

The above conditions show that empowerment programs carried out by stakeholders have not shown significant impacts on the socio-economic improvement of coastal communities. For example, the Community Salt Business Empowerment Program (PUGAR) has had a decline in production yields every year which is an average of $8 \%$ since 2013. If stakeholders have not been able to recommend improvements to management that affect the decline in the achievement of the PUGAR salt production program in Bima Regency such as the use of technology that is still classified as traditional, increasing cooperation partners of farmers who are currently still dependent on middlemen, as well as uncertain prices in the harvest season will certainly cause a significant reduction in salt production which will also affect the motivation and income of salt farmers in the coastal areas of Bima Regency.

In the aspect of environmental protection, the typical resources that are threatened are in the coastal areas and small islands of BimaRegency is a mangrove forest. The causes of damage, other than caused by coastal communities such as the use of mangrove wood for cooking needs and extensification of pond land, residential areas, also due to the intervention of the capital development plan in the southern part of Bima Regency. The government plans to build and extend the runway of Sultan Muhammad Salahuddin Airport of Bima Regency, even though there are dozens of hectares of natural mangrove areas around the airport.

Tabel 1. Mangrove Forest Condition in Bima

\begin{tabular}{ccccc}
\hline Year & Mangrove area $(\mathbf{H a})$ & $\begin{array}{c}\text { Good } \\
(\mathbf{H a})\end{array}$ & $\begin{array}{c}\text { Medium Damaged } \\
(\mathbf{H a})\end{array}$ & Badly Damaged (Ha) \\
\hline 2013 & 861,68 & 102.69 & 307,85 & 451,14 \\
2016 & 550,8 & 158,79 & 125,07 & 266,95 \\
\hline
\end{tabular}

Source: Data on the Potential of Ecosystems, Energy and Marine Resources, Coastal and Marine Resources The small islands of Bima district (2014)

The area of mangrove forests from year to year experienced a significant reduction. So that in the effort of mangrove protection and reabilitation, each sector has a different approach. The Department of Marine and Fisheries conducted data collection and identification of the extent of damage to the area, determination of the location of rehabilitation areas, nurseries and indetifications for the suitability of mangrove species with the area, planting mangroves to their supervision in coastal areas carried out through community empowerment approaches.

In contrast to the approach taken by the Environment Agency that uses third parties in this case the use of private services for the procurement of mangroves. Empowerment of community groups is intended to improve the community's perspective on the environment, which has been intervening and damaging so that it can help in the conservation of mangroves.

One of the problems faced is the large number of people who have opened businesses and even have mastered the coastal area, without any effort from the government to reduce the limit of land ownership in coastal areas. So that the community, capital owners, and others who have interests in the coastal area are free to convert mangroves into a place of residence for coastal communities, 
ponds and fish drying places. As a result, the mangrove conservation area has diminished with the adverse impacts on socio-economy and the environment that follows.

\section{Conclusion}

Sustainable development of coastal and small islands in Bima Regency is still a major problem faced by all stakeholders. Weaknesses in efforts to distribute income and welfare, especially for the provision of socio-economic infrastructure in coastal communities. The high number of underprivileged households in the coastal area as evidence of weakness in socio-economic development of the community. As for the aspect of environmental protection, the efforts made by stakeholders are the rehabilitation of coastal resources and small islands to balance the carrying capacity of social, economic and environmental protection.

In this effort, the government uses two approaches, namely group empowerment and the use of private services. However, these efforts are inversely proportional to the narrowing of the mangrove conservation area.

Infrastructure improvements and provision of facilities, as well as tourist facilities and infrastructure as an effort to increase tourist visits both locally and internationally with the aim of boosting the economy of coastal communities. In addition, the need to improve the empowerment of coastal communities, and creative economy groups, regional governments must also be able to establish partnerships with local and international entrepreneurs to support the tourism development of Bima Regency. Law enforcement must also be done through giving strict sanctions for those who exploit coastal resources and small islands.

\section{References}

[1] Soerjani, Lingkungan: Sumber daya Alam dan Kependudukan dalam Pembangunan. Jakarta: Universitas Indonesia Press, 2008.

[2] Harahab, Penilaian Ekonomi Ekosistem Hutan Mangrove dan Aplikasinya dalam Perencanaan Wilayah pesisir, 1st ed. Yogyakarta: Grahallmu, 2010.

[3] D. Ferrol-Schulte, P. Gorris, W. Baitoningsih, D. S. Adhuri, and S. C. Ferse, "Coastal livelihood vulnerability to marine resource degradation: A review of the Indonesian national coastal and marine policy framework," Mar. Policy, vol. 52, pp. 163-171, 2015.

[4] R. Dahuri, "Paradigma baru pembangunan Indonesia berbasis kelautan," vol. 1, no. 1-2, pp. 65-71, 2003.

[5] A. R. Farhan and S. Lim, "Assessment of Ocean and Coastal Policy Effectiveness in Seribu Islands, Indonesia," Int. J. Geoinformatics, vol. 10, no. 3, 2014.

[6] Iskandar, Psikologi Lingkungan "Teori dan Konsep," 1st ed. Bandung: Refika Aditama, 2012.

[7] D. Armitage, F. Berkes, and N. Doubleday, "Adaptive co-management: collaboration, learning, and multi-level governance.” UBC Press, 2010.

[8] A. Keraf, Etika Lingkungan Hidup. Jakarta: Kompas, 2010.

[9] J. Ife and F. Tesorioro, Community Development alternative Pengembangan masyarakat di era globalisasi. Yogyakarta: Pustaka Pelajar, 2014. 
[10] "Bimakab.go.id." .

[11] M. B. Miles, A. M. Huberman, and J. Saldana, Qualitative Data Analysis A Methods Sourcebook, 3rd ed. The USA: Arizona State University. 